\title{
Correlation Between Cone Resistance Values and Cohesion Values in Cohesive Soils (Case Study in Gunung Anyar District)
}

\author{
Fithri Estikhamah*, Dian Purnamawati Solin \\ UPN Veteran East Java, Civil Engineering Department, Indonesia
}

\begin{abstract}
The physical and mechanical properties of the soil can be determined based on laboratory tests by testing soil samples obtained from field drilling. At one point it can be done simultaneously between SPT testing and drilling. Therefore, it can be known simultaneously the value of N-SPT with the physical and mechanical properties of the soil. The purpose of this study was to obtain a relationship between the cone resistance value (qc) obtained in the field and the cohesion value for cohesive soil types. This study uses primary data, and secondary data. The results of the correlation between the cone resistance value (qc) obtained in the field and the cohesion value for cohesive soil types show a strong correlation. This is indicated by the regression value which reaches a value of 0.75 , which is 0.7809 . The regression equation obtained is $y=0.0138 x-0.0063$. The coefficient of the cone resistance value is 0.0138 , indicating that every 1 constant increase in the cone resistance value variable will increase the cohesive value in the cohesive soil by 0.0138 . The positive regression coefficient indicates that the higher the cone resistance value (qc), the higher the value of cohesion (c) for cohesive soils.
\end{abstract}

Keywords: Cone Resistance Values, Cohesion Values, Cohesive Soils

\section{Introduction}

It is very important in designing a foundation is the availability of accurate soil data.[1] In designing a building foundation, the bearing capacity of the soil is a very important element. Tests in the field that are most often carried out are sondir test or static cone penetration test (CPT).[2] This sondir test is very useful in the test conditions of soft clay and sand.[3] The value of static cone resistance or cone resistance (qc) and outer pipe friction resistance ( $\mathrm{fs}$ ) is the result of this test. This study was conducted to examine the correlation of the cone resistance value (qc) with the cohesion value (c) for cohesive soil types. For data retrieval using sondir test because at the time of doing the test can be obtained qc value from the manometer reading. Meanwhile, to get the correlation value using the excel program.

\subsection{Preliminary Field Investigation}

Preliminary investigations are needed to identify the type of soil present and obtain information on how deep the soft soil deposits are so that a detailed investigation can be planned at an appropriate cost. Soil sampling for surveying and drilling should be carried out to obtain important information such as the depth of the soft soil layer, the consistency of the soft soil, the type of soft soil, and the soil profile.
Detailed information on a soil condition below the surface requires the required soil depth. Thus, to obtain a general geological picture of the location of the sampling point, it is necessary to take the investigation point in such a way.

\subsection{Soil Clasification from Sondir Data}

Sondir test or known as static cone penetration test is widely used in Indonesia. This test is a test used to calculate the bearing capacity of the soil. The values of static cone resistance or cone resistance (qc) obtained from the test can be directly correlated with the bearing capacity of the soil [4-6]. In sondir test, there is a complex change of soil stress during penetration so that which complicates theoretical interpretation. Thus, although theoretically the interpretation of the sondir test results already exists, in practice the sondir test remains empirical.[7]

Cone pressure data (qc) and adhesive resistance (fs) obtained from the sondir test results can be used to determine the type of soil as shown in Table 1. [8]

\footnotetext{
* Corresponding author : fithri.ts@upnjatim.ac.id
} 
Table 1. Soil Classification from Sondir Data

\begin{tabular}{|l|l|l|}
\hline \multicolumn{2}{|c|}{ Hasil Sondir } & \multicolumn{1}{c|}{ Klasifikasi } \\
\hline \multicolumn{1}{|c|}{ qc } & \multicolumn{1}{|c|}{ s } & \\
\hline 6.0 & $0.15-0.40$ & $\begin{array}{l}\text { Humus, very soft clayg sangat } \\
\text { lunak }\end{array}$ \\
\hline $6.0-$ & 0.20 & $\begin{array}{l}\text { Loose silty sand, very loose } \\
\text { sand }\end{array}$ \\
\cline { 2 - 3 } 10.0 & $0.20-0.60$ & Soft clay, soft silty clay, clay \\
\hline \multirow{2}{*}{$30.0-$} & 0.10 & Loose Pebbles \\
\cline { 2 - 3 } & $0.10-0.40$ & Loose sand \\
\cline { 2 - 3 } & $0.40-0.80$ & Clay or silty clay \\
\cline { 2 - 3 } & $0.80-2.00$ & The clay is a bit chewy \\
\hline $30-60$ & 1.50 & Silt sand, slightly dense sand \\
\cline { 2 - 3 } & $1.0-3.0$ & Clay or silty clay \\
\hline $60-150$ & 1.0 & Sandy pebbles loose \\
\cline { 2 - 3 } & $1.0-3.0$ & $\begin{array}{l}\text { Solid sand, silty sand or solid } \\
\text { clay and silty clay }\end{array}$ \\
\cline { 2 - 3 } & 3.0 & Chewy gravel clay \\
\hline 150 & $1.0-2.0$ & $\begin{array}{l}\text { Dense sand, gravel sand, coarse } \\
\text { sand, very dense silt sand }\end{array}$ \\
\hline
\end{tabular}

Source: Soil Mechanics Book, Braja M. Das Vol.1

While the relationship between the consistency of cone pressure and undrained cohesion is comparable where the higher the value of $\mathrm{c}$ and $\mathrm{qc}$, the harder the soil. As can be seen in Table 2. [9]

Table 2. Relation Between Consistency and Cone Pressure in Clay Soil

\begin{tabular}{|c|c|c|}
\hline Soil Consistency & $\begin{array}{c}\text { Cone Pressure qc } \\
\left(\mathrm{kg} / \mathrm{cm}^{2}\right)\end{array}$ & $\begin{array}{c}\text { Undrained } \\
\text { Cohesion } \\
\left(\mathrm{T} / \mathrm{m}^{2}\right)\end{array}$ \\
\hline Very Soft & $<2,50$ & $<1,25$ \\
Soft & $2,50-5,0$ & $1,25-2,50$ \\
Medium Stiff & $5,0-10,0$ & $2,50-5,0$ \\
Stiff & $10,0-20,020,0-$ & $5,0-10,0$ \\
Very Stiff & 40,0 & $10,0-20,0$ \\
Hard & $>40,0$ & $>20,0$ \\
& & \\
\hline
\end{tabular}

Source: Begeman, 1965

\subsection{Cohesion}

Cohesion is the attractive force between soil particles. Together with the internal shear angle, cohesion is a parameter of soil shear strength that determines the soil's resistance to deformation due to stresses acting on the soil in this case in the form of lateral soil movements. This deformation occurs due to a combination of critical conditions under normal stresses and shear stresses that are not by the planned safety factor. This value is obtained from the Triaxial Test and Direct Shear Test. The value of cohesion empirically can be determined from the sondir data (qc) as follows: Cohesion $\mathrm{c}=\mathrm{qc} / 2$. [10]

\section{Research Methodology}

The methodology used in this research are:

1. Primary data collection

The source of this research data is obtained from field tests that are carried out directly to get sondir and boring. The location of data collection is in East Surabaya.
2. Secondary data collection

The source of data for this research comes from documents of deep boring work in the East Surabaya area. The data was obtained in the form of summary data of laboratory test results (summary laboratory test results) and borlog data.

3. Data analysis

Analysis of the data using the excel program to get the results of the correlation between the value of cone pressure (qc) to the value of cohesion in cohesive soils.

\section{Analysis and Discussion}

By using the Excel program to get the correlation value between the cone pressure value (qc) and the cohesion value (c).

\subsection{Correlation Between CPT and Cu}

The qc value of the CPT (Cone Penetration Test) can be correlated with the $\mathrm{Cu}$ value. The following is the equation to determine the $\mathrm{Cu}$ value.

Where :

$$
\mathrm{C}=\frac{c_{u}-\sigma_{v}}{N k t}
$$

$\mathrm{qc}=$ Cone Resistance

$\sigma_{v}=$ Effective Strength

$\mathrm{N}_{\mathrm{kt}}=$ Cone factor $(10-18)$

\subsection{Analysis Correlation}

Correlation Analysis is an analysis used to determine the close relationship between several variables. [11] Usually, this correlation test will be closely related to the regression test which shows whether each variable influences the other. Although these variables are closely related or correlated, they do not necessarily influence each other. In this correlation analysis, the output produced is only in the range of -1 to 1 and is divided into positive correlation (positive result), negative correlation (negative result), and no correlation at all (0).

Table 3. Correlation Results Between Conical Pressure Value (qc) and Cohesion Value Using Data Analysis

\begin{tabular}{lrr}
\hline & Column 1 & Column 2 \\
\hline Column 1 & 1 & \\
Column 2 & 0,780905 & \\
\hline
\end{tabular}

The correlation of any variable with itself must result in 1 so it doesn't need to be noticed. In this analysis, it is enough to see the correlation value generated between the cone pressure value (qc) and the cohesion value (c), where the result is 0.780905 .

These results indicate that the conical pressure variable (qc) obtained has a close relationship with the cohesion value in cohesive soil conditions, where the correlation value is 0.780905 , which means it is positively related. This positive meaning is that when 
the cone pressure value $(\mathrm{qc})$ increases, the cohesion value (c) in the cohesive soil will also show an increase in value.

To show how much influence the value of cone pressure (qc) has on the value of cohesion (c) on cohesive soils, a regression test is carried out using the Excel program.

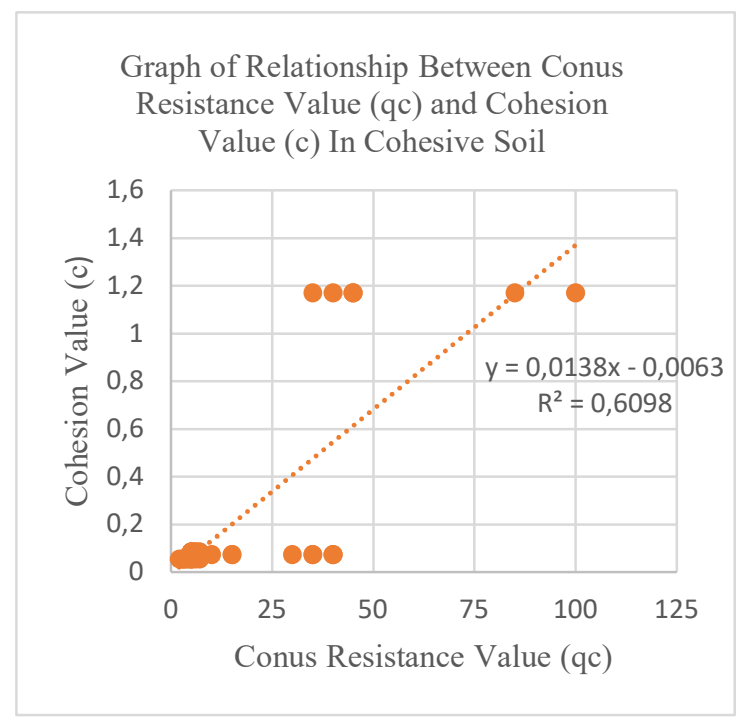

Fig. 1. Graph of Relationship Between Cone Resistance Value (qc) and Cohesion Value (c) In Cohesive Soil

From the graph above, the value of $\mathrm{R} 2=0.6098$ is obtained; with a value of $\mathrm{R}=0.7809$. This shows that the correlation between the cone resistance value (qc) and the cohesion value (c) in cohesive soils has a very strong correlation with the regression equation, which is $y=0.0138 x-0.0063$. The coefficient of the cone resistance value is 0.0138 , indicating that every 1 constant increase in the cone resistance value variable will increase the cohesive value in the cohesive soil by 0.0138 . The positive regression coefficient indicates that the higher the cone resistance value (qc), the higher the value of cohesion (c) for cohesive soils.

\section{Conclusion}

From the results of the study, it can be concluded that the higher the cone resistance value (qc), the higher the cohesion value (c) for cohesive soils.

Authors gratefully thanks the programme UPN Veteran East Java, for supporting this research through an Institutional Research grant.

\section{References}

1. Bowles, J. E. (1997). Foundation Analysis and Design, Fifth Edition. The. McGrawHill Companies Inc. New York.

2. Meyerhof, G.G. (1956). "Penetration Test and Bearing Capacity of Cohesi on less Soil." Journal of the Soil Mechanics and Foundations Division.
American Society of Civil Engineers. Vol. 82. No. SM-1. pp. 1-19

3. Jarushi, F., AlKaabim, S., dan Cosentino, P.. (2015). A New Correlation Between SPT and CPT for Various Soils. International Journal of Environmental, Chemical, Ecological, Geological and Geophysical Engineering. 9 (2) .pp.101-107.

4. Hardiyatmo, H.C.. (2002). Soil Mechanics 1 First Printing Third Edition. Yogyakarta: Gajah Mada University Press.

5. Hardiyatmo, H.C. (2010a). Analysis of Foundation Design Part 1. Yogyakarta: Gajah Mada University Press.

6. Hardiyatmo, H.C. (2010b). Soil Mechanics 2 First Printing Fifth Edition. Yogyakarta: Gajah Mada University Press.

7. Rahardjo, P. P. (2008). Geotechnical Investigation with Insitu Test. GEC UK-Parahyangan, Bandung.

8. Das, B.M.. (1988). Soil Mechanics Volume 1 (Principles of Geotechnical Engineering). Erlangga: Jakarta.

9. Begeman, Myron L. (1965). Mechanical Technology. Jakarta: Erlangga.

10. Sunggono K. H. Ir. (1984). Civil Engineering Book. Nova, Bandung.

11. Ali, Sambas. (2007). Correlation, Regression and path Analysis in Research. Bandung Pustaka Setia. 